\title{
Change and continuity in managerialism: 100 years of administrative history at the International Museum of Ceramics in Faenza
}

\author{
Maria Lusiani University of Bologna
}

Luca Zan University of Bologna

\begin{abstract}
This paper offers a long-term perspective on the debate on managerial transformations in the public sector: how public sector organisations actually arrived at such changes, what processes, discourses and practices are transformed and how. This is investigated through archival research and a longitudinal analysis of 100 years of the administrative history of an Italian museum. Taking a historical perspective allows us to account for organisational changes that occurred over time, including major reforms in the governance structure and the dynamics of some core managerial features. Such an approach enables a more in-depth, empirically grounded and historically aware discussion on the so-called rise of managerial issues in the public sector.
\end{abstract}

Key words • archival research • institutional change $\bullet$ managerialism • management history - modernisation • museum management $•$ New Public Management

\section{Introduction}

The managerial transformation of the public sector has come to the central attention of a growing stream of management research in the past decades. The phenomenon has been critically scrutinized in the literature - both at the macro level, investigating the socio-political rationales of public sector reforms, and at the micro level, exploring the impacts and also the shortcomings of managerialism in public organisations (concerning the introduction and appropriation of values, techniques, governance structures and practices in the business world). Much research has thus accumulated on recent public sector changes; however, much less is known about longer trends and about how public organizations were administered prior to the 'advent of managerialism'. 
We investigated 100 years of administrative history in an Italian museum. This museum presents significant dynamics in terms of relations with the public sector, in that it changed its governance structures from private to direct public control, and back again to more private-like forms. In reconstructing this history we were confronted with two views: on the one hand, the museum professionals' view, which shared a narrative of exceptional modernity of the origins in the management of the museum; on the other hand, the New Public Management debate, which conceives managerialism as the outcome of a modernisation process.

The goal of this paper is to question the two apparently contradictory narratives concerning the modernisation of the museum through an archival analysis, and by so doing deepen the debate on recent trends in public sector transformation, and the historical antecedents of managerialism.

Our main findings can be summarised as follows. Some features of managerialism (namely, autonomy, accountability and market orientation) are evident in the administration of the museum since its foundation; the alleged novelty of managerialism in public administration is thus to some extent falsified. However, a deep analysis also reveals that the 'modernity' of the origin of the museum is to some extent rhetorical in nature, when the gap between intention and action is taken into account. Moreover, there are elements of managerialism that are rather borne by more recent trends too. In sum, our case history shows the complexity and the nonlinear nature of organizational change, in contrast to more simplistic views. We argue that a notion of complexity over time should be seriously taken into account in order to understand change. In this light, we conclude that the management literature in general, and the public management debate in particular, would largely benefit from more historical investigations.

In the next section we present the background of the debate on managerialism and position our case history within the two alternative narratives. Next, we illustrate the method of our study, outline the administrative history of the museum and therein trace three relevant features of managerialism (autonomy, accountability and market orientation). Finally, we discuss our findings and provide some concluding remarks.

\section{Background: Managerialism and the International Museum of Ceramics}

\section{Managerialism and modernisation}

The transformation of the public sector is a worldwide phenomenon that in the last decades has emerged in various countries at different speeds and in different ways. The general phenomenon has been extensively addressed by management literature and referred to as New Public Management (Bowerman 1996; But and Palmer 2000; Gruening 2001; Hood 1991; Lapsley 1988; Lindkvist and Llewellyn 2003). Despite the variations of managerial reforms across different contexts and countries (Hood 1995), and despite severe criticism about the abuses of managerial rhetoric often 
characterising the literature (Zan 2006), some common features seem to be shared by all notions of managerialism.

One of these crucial aspects is the notion of autonomy of public entities. Autonomy can be conceived in two main ways: governance autonomy and autonomy over resource management. Governance autonomy concerns an entity's legal status, often involving the adoption of juridical personality, the ability to nominate the governing body and identity-affirmation practices involving 'formulation of statutes, mission stating, policy stating' and the like (Brunsson and Sahlin-Andersson 2000). Autonomy over resources management is conceived as self-regulation for an entity, concerning direct control of resources without a central regulatory system and a central itemised budget (Brunsson and Sahlin-Andersson 2000); in other words, a 'hands-on top management', having managers 'free to manage' with wide discretion (Hood 1995). In particular, it can be articulated into autonomy over financial resources and human resources management.

Another crucial feature of managerial transformation is the one of accountability. Managers free to manage have to be publicly accountable for their choices; this means that they must be responsible and transparent about the use of resources and about its connection to goals and results. Therefore, managerialism is associated with the clarification of goals and strategic positioning, and the establishment of planning, budgeting and reporting systems (accounting) in relation to those preset goals (Ferlie 2002; Hood 1995).

A third aspect common to managerialism is the notion of market orientation. This tends to be conceived in three ways at least: (i) the development of quasi-markets (organisations that are publicly owned, but increasingly open to private investors or organisations that couple a hierarchy structure with outsourcing and contracting out solutions - Ferlie 2002); (ii) a commercial orientation, i.e. profit-seeking activities; and (iii) outward orientation, i.e. public organisations conceiving the citizen as a 'client', thus focusing outward on how to reach the public (marketing and communication activities) and on issues of customer care, like the perceived quality of the service.

There is a dominant position in the literature concerning the fact that industrialised countries have approached management processes and notions in the attempt to modernise their public sector (Hood 1995; Johnsen and Lapsley 2005; Lapsley 2008; Pollitt 2002) as a response to the growing complexity of the world. Public administration is associated with a notion of bureaucracy and past times, an era that is being or should be overcome, while the New Public Management (in its name itself) is associated with a notion of progress, change and modernity. In other words, in mainstream thought, 'modern' and 'management' in the public sector coincide.

However, in the literature on public sector reform, little archival research has been conducted that adopts a historical perspective. A narrow focus on recent changes fosters the un-problematised assumption that before the reforms of the last decades, public organisations were in a sense 'primitive', not proactive, mainly focused on the status quo, and were characterised by a lack of 'modern' forms of 
management. Within the management field, studies investigating public organisations through a historical perspective, trying to account for organisational processes and transformations over time, are indeed rare (with few exceptions: see e.g. Zan 2004). These studies showed that not only were rather sophisticated accounting practices in place, but that some forms of managerial discourse are far older than the 'invention' of management studies (e.g., at the Venice Arsenal at the turn of the sixteenth century).

Therefore, the question arises: what was there before NPM? What is the public sector reform actually transforming? To what extent is the managerialisation of public sector organisations a recent phenomenon? Is there an historical development towards managerialism?

These are the issues that this paper intends to address. In particular, our analysis will be organised around the main features of managerialism that we derived from the literature: autonomy, accountability and market orientation.

\section{The MIC between different narratives}

This paper analyses the administrative history of the Museo Internazionale delle Ceramiche (International Museum of Ceramics, hereinafter MIC), an internationally renowned museum in the field of ceramics, located in Faenza, Italy. When considering the MIC's administrative history in terms of managerialism and modernisation, we could face two different narratives. On the one hand, museology professionals and historians share a 'heroic' representation of this museum as an exceptionally modern and proactive institution since its origins (e.g. Balzani 2008; Bentini 2008). Their acknowledgement of the history of the museum is usually confined to the first decades of the century, being focused on the 'epic' character of the founder Gaetano Ballardini. The MIC history is portrayed as the story of an idea that becomes reality and that already embodied elements of a modern, internationalised concept of a museum (e.g. its educational vocation, its emphasis on promoting young artists, its tie with the ceramic industry and with commercial fairs).

On the other hand, and more broadly, the mainstream (ahistorical) management literature embraces another heroic narrative: that of management as the bearer of modernisation. In this view, MIC would be interpreted as an organisation that in the last decades went through a process of managerialisation, moving from a bureaucratic, steady public management embedded in the municipal administration to increased autonomy, a more transparent and complete accountability and a growing quasimarket orientation as far as its recent transformation into an operating foundation, in 2002 , is concerned.

This is puzzling referring to our case history. What we are facing are two apparently contradictory narratives: the museology professional view at MIC, and the management studies view in the broader debate. What about modernisation at MIC? Is it the story of a modern and proactive entity since its origins as evoked by 
museologists and by the museum staff today; or is modernity the outcome of a recent transformation from public sector bureaucracy towards managerialism, consistent with the NPM literature?

Revisiting management issues through a historical analysis over such a long period of time could add some important elements in bridging and reconsidering both views.

\section{Methods}

MIC was not selected for being a somehow representative case. The choice to reconstruct its administrative history was driven instead by two other reasons. First, the availability of rich archival sources. Second, the fact that since its establishment in 1908, MIC went through several major transformations, using different governance forms that ranged from private to direct public control, back to more private-like institutional arrangements. This made MIC an interesting case history in the light of the literature on public sector privatisation and désétatisation (Hemel and van der Wielen 1997), also presenting the description of a phenomenon previously overlooked by the literature: that of étatisation.

The historical analysis is conducted on the base of the minutes of the meetings of the resident council (i.e. the MIC board of directors) and other formal documents (the statutes and the financial reports), covering almost 100 years of administrative history, from the very establishment of the museum until the present times. We chose to end our analysis in 2001, leaving out the most recent and ongoing administrative history of the present foundation, which would deserve a separate ad hoc analysis that is not a purpose of this paper.

We conducted a thematic analysis of all the minutes of the resident council meetings between 1908 and 2001. As a first step, we applied an open coding approach: 14 themes emerged from our data; half of them were mainly dealing with administrative issues and half were mainly dealing with substantive, professional ones (museum collections, exhibitions, editorial activity, etc.). Since our goal was to trace managerialism throughout time, for the purpose of this paper we selected those themes that explicitly concerned administrative aspects. As a second step, we derived above-mentioned main features of managerialism from the NPM literature and related them to the administrative themes that had emerged from our archive data. The resulting structuration of themes is presented in Table 1.

Elements of variability and elements of continuity in organisational processes, practices and discourse could then be addressed. In turn, this led to the emergence of several analytical periods and sub-phases in the history of the museum.

Presenting a 100-year history under space constraints is very difficult. The risk to trivialise complex processes over time and to give simplistic and un-problematised views is a major concern. Therefore, a richer description of archival findings is available on SSRN as a sort of 'attachment' to this paper, a virtual appendix (Lusiani and 
Table I Structuration of themes

\begin{tabular}{lll}
\hline Theme & Sub-theme & Sub-sub-theme \\
\hline Autonomy & $\begin{cases}\text { Governance } & \left\{\begin{array}{l}\text { Legal status } \\
\text { Identity/mission stating }\end{array}\right. \\
\text { Resources management } & \left\{\begin{array}{l}\text { Financial resources } \\
\text { Human resources }\end{array}\right. \\
\text { Accountability } & \begin{cases}\text { Planning } \\
\text { Accounting }\end{cases} \\
\text { Market orientation } & \left\{\begin{array}{l}\text { Quasi-market } \\
\text { Reporting }\end{array}\right. \\
\text { Commercial orientation } \\
\text { Customer orientation }\end{cases}$ & $\left\{\begin{array}{l}\text { Private investors } \\
\text { Outsourcing } \\
-\end{array}\right.$ \\
\end{tabular}

Zan 2009). The reader who wishes to better understand what was happening - and check our own process of sense-making among the enormous amount of information can easily access this additional descriptive and in-depth analysis.

\section{A preliminary periodisation}

The analysis is articulated into two sections. First, as a general framework, we will briefly describe the historical development of the museum over time, identifying various phases, periods of continuity and change (periodisation). Next, we will explore more in-depth the selected core elements of managerialism and their dynamics over time.

Throughout its 100 years of existence, the museum went through different administrative forms. The historical reconstruction follows the administrative periods determined by these major governance transformations:

1908-1976 Moral entity, a privately run kind of entity.

1976-1996 Municipal museum.

1996-2001 Istituzione, a relatively autonomous entity of the local municipality.

2002 - present A private-law operating foundation.

Within each of these periods several different patterns emerged, which in turn led to the identification of specific organisational phases (Table 2).

\section{MIC as a moral entity (1908-1976)}

By the time of its establishment in 1908 and up to 1976, MIC had been an autonomous Moral entity (a specific form for simple private economic activity). It had juridical personality and was managed by a board of directors, called the resident 


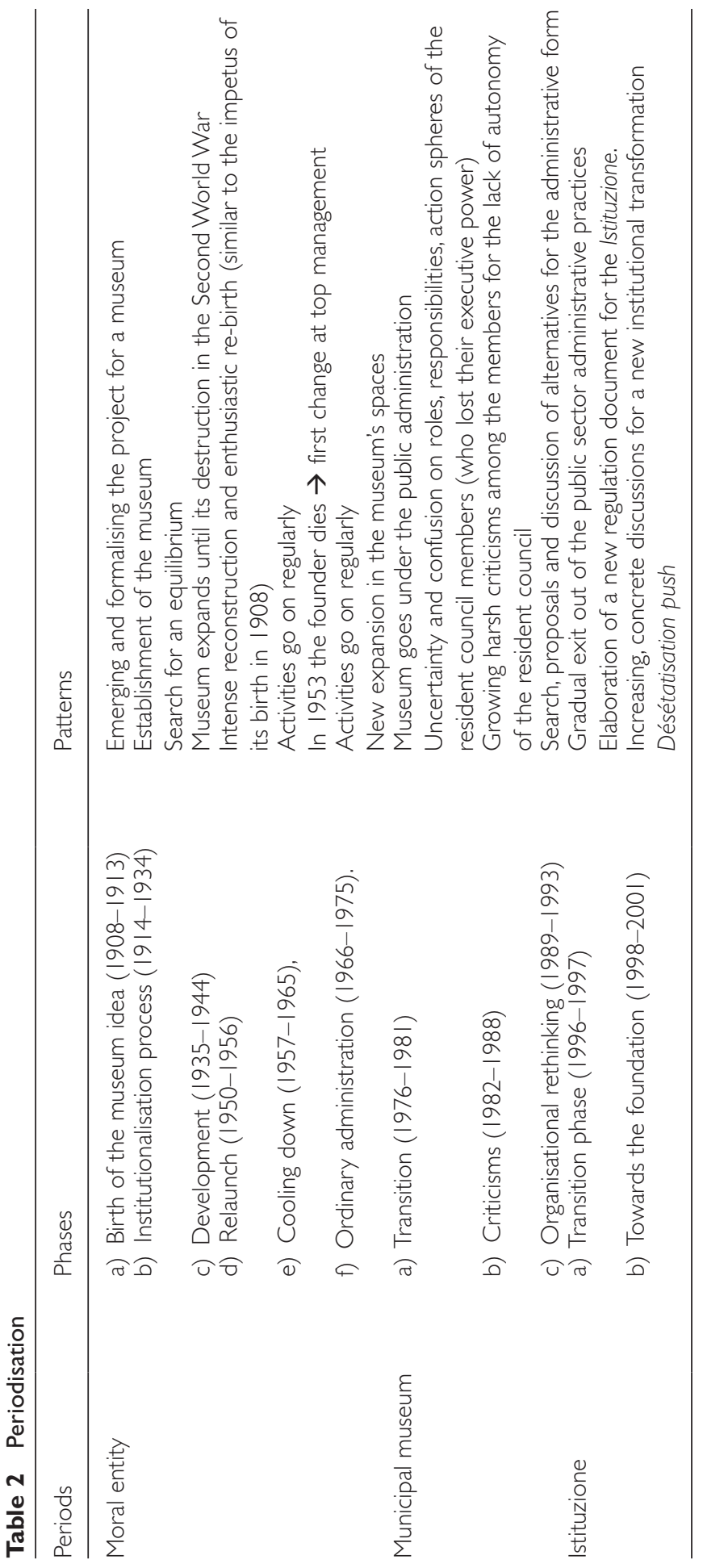


council, composed of its founder Gaetano Ballardini (also chairman and executive director of the museum) and other co-founding members. Spaces and collections of the museum formally belonged to the Municipality of Faenza, and the museum was largely funded by municipal and ministerial grants.

The museum was established using a bottom-up process, upon the will and effort of its very charismatic leader, his network of relationships to relevant public and private actors (collectors, ceramic manufactories, investors, etc.), and the strong support of the local and national public administration.

In 1908, the founding committee formulated the organisational goals and a statute: the idea of the museum even preceded the museum itself. The collections were accumulated over the following decades; only a tiny core of objects was in place at the time the museum was established. Beside more general goals of museum activity (such as conservation, exhibition of artistic production and research), the goals set explicitly included:

- collaboration with industrial ceramic manufacturers;

- establishment of an international competition for contemporary ceramic artists;

- establishment of a professional school within the museum to revive the ceramic tradition; and

- editing a journal on the industrial and artistic activity in the ceramic field.

Overall in this period, the discussions in the resident council meetings reflect the story of the birth, expansion and institutionalisation of a new organisation. In parallel, data on the growth of financial flows, activities, collections, spaces and staff attest to the expansion of the museum.

A big fracture was created by the destruction of the museum and its collections in 1944 under the bombing of the Second World War, causing the institution to close. One of director Ballardini's manuscripts from May 1944 speaks for itself: 'After 40 years of strenuous work we must start everything over again.'

At the beginning of the 1950s, Ballardini himself reassembled the resident council and promoted the relaunch of the museum. A phase of intense reconstruction began: the restoration of premises, a call for ceramic donations (entire collections were donated from all over the world), an explosion of exhibitions and participation in trade fairs, and the relaunch of journal publication activity. Therefore, despite the destruction of the war, not much had changed at MIC: not its core identity, nor the governance structure, nor its policies and distinctive activities.

In 1953, Giuseppe Liverani was appointed director after Ballardini’s death. Under Liverani, the reconstruction impetus cooled down and all activities continued regularly for about 20 years of ordinary administration, until 1976.

\section{MIC as a municipal museum (1976-1996)}

The second macro-period of the MIC administrative history was triggered by the first, radical transformation of the museum in 1976. Such transformation was desired 
by the director and implemented according to changes in regional legislation. Its rationale was to obtain financial stability through the institutionalisation of a major and stable annual fund both from the region and the municipality. The context is that of the process of establishment of regions as administrative entities in Italy (started in the early 1970s), wherein the Emilia Romagna region already had a tradition of superior quality in public administration and public services.

On the substantive level, the reform entailed the suppression of MIC's juridical personality and its inclusion under the direct municipal administration. On the procedural level, many organisational processes changed: resident council members had to be appointed by the town council and would turn over with the end of the political mandates; personnel were directly hired and managed at the municipal level; and the museum had to submit activity programme proposals and budget proposals to the municipal administration for approval.

This situation lasted 20 years. These two decades were characterised by an emergent awareness among the board members of the unintended consequences of the reform - i.e. their loss of control over decisions and resources. This - coupled with delays and shortage in the supposedly stable regional funding - caused growing discontent in the resident council. It led the members to a major process of rethinking to find a new administrative form that would provide the museum with more secure funding and, above all, return to the resident council some of its former autonomy.

Despite the turbulence at the top management level and the paucity of resources, the institutional activities of the museum kept on throughout this period.

\section{MIC as an Istituzione (1996-200I)}

The third macro-period of the MIC administrative history was marked by the exit of the museum from direct and total municipal control and by its formal transformation into a new administrative form: the Istituzione - an administrative form identified by the Italian legislation on local public administration (Law 142/1990). Formally, the Istituzione is an instrumental branch of the municipality, not provided with a juridical personality, yet holding a considerable level of autonomy over the management of financial resources, human resources and core activities, under the control of the public administration. If the first formal reform of the museum in 1976 had been an under-planned and topdown process, the solution of the Istituzione was instead the output of a formal search conducted by a committee of board members and external legal consultants.

In the case of MIC, the legal form of the Istituzione was expected to confer a distinctive/separate identity to the museum among the other cultural activities of the municipality, to provide the museum management with responsibility over the use of resources (e.g. the museum would present its own financial statements again) and more generally to ensure more rapid and less bureaucratic forms of decisional processes.

The experience of MIC as an Istituzione was indeed very short, lasting just five years. It should be noted that soon after its establishment, the museum's top management 
began to regard the Istituzione as a temporary solution that would bridge to a more radical form of privatisation (a private operating foundation).

During this period two phases emerged. The first (1996-1997) was the transition phase in which the museum management gradually rehabilitated part of its former autonomy and control. However, this took place in a state of confusion about the actual new roles and responsibilities of the board, coupled with excessive expectations of an immediate and more radical detachment from municipal control. The second phase (1998-2001) was characterised by preparations for the transformation of the museum into a private foundation. This goal, strongly pursued by the museum director, was driven by the fashionable new wind of 'privatisation' and its associated concepts of autonomy, flexibility, emancipation from the bureaucratical and politicised public administration, attraction of private capital, and the like.

\section{Tracing managerialism in a 100 -year period}

In this section we will trace the dynamics of the core features that - according to the literature - characterise the managerial discourse of the new public sector: autonomy (with focuses on governance and resources management), accountability (with focuses on planning and accounting) and market orientation (with focuses on quasi-market, commercial orientation and customer orientation). Elements of change and continuity are presented in Table 3. This section is based on the analysis of the resident council meetings (RCM) minutes.

\section{Autonomy}

\section{Governance autonomy}

Governance autonomy is crucial to the notion of managerialism. MIC moves from a long period of complete autonomy when it was a Moral entity, into a period of loss of autonomy when it went public, under the municipality, to a process of gradual (re)acquisition of autonomy as an Istituzione. Two typical aspects concerning governance autonomy will be raised: legal status and identity setting (Table 3 , columns 5-6).

Initially, MIC was founded as an autonomous entity (formal recognition and legal personality of the moral entity were obtained in 1912 by Royal Decree), depending upon the town council only for an annual grant and for the concession of premises for use. During the 20-year period of the municipal administration, the issue of autonomy emerged as the main theme animating the resident council: the transformation into a municipal museum in 1976 - pursued by the top management to secure financial stability - caused the complete loss of autonomy for the resident council. First of all, MIC lost its juridical personality in favour of the town 


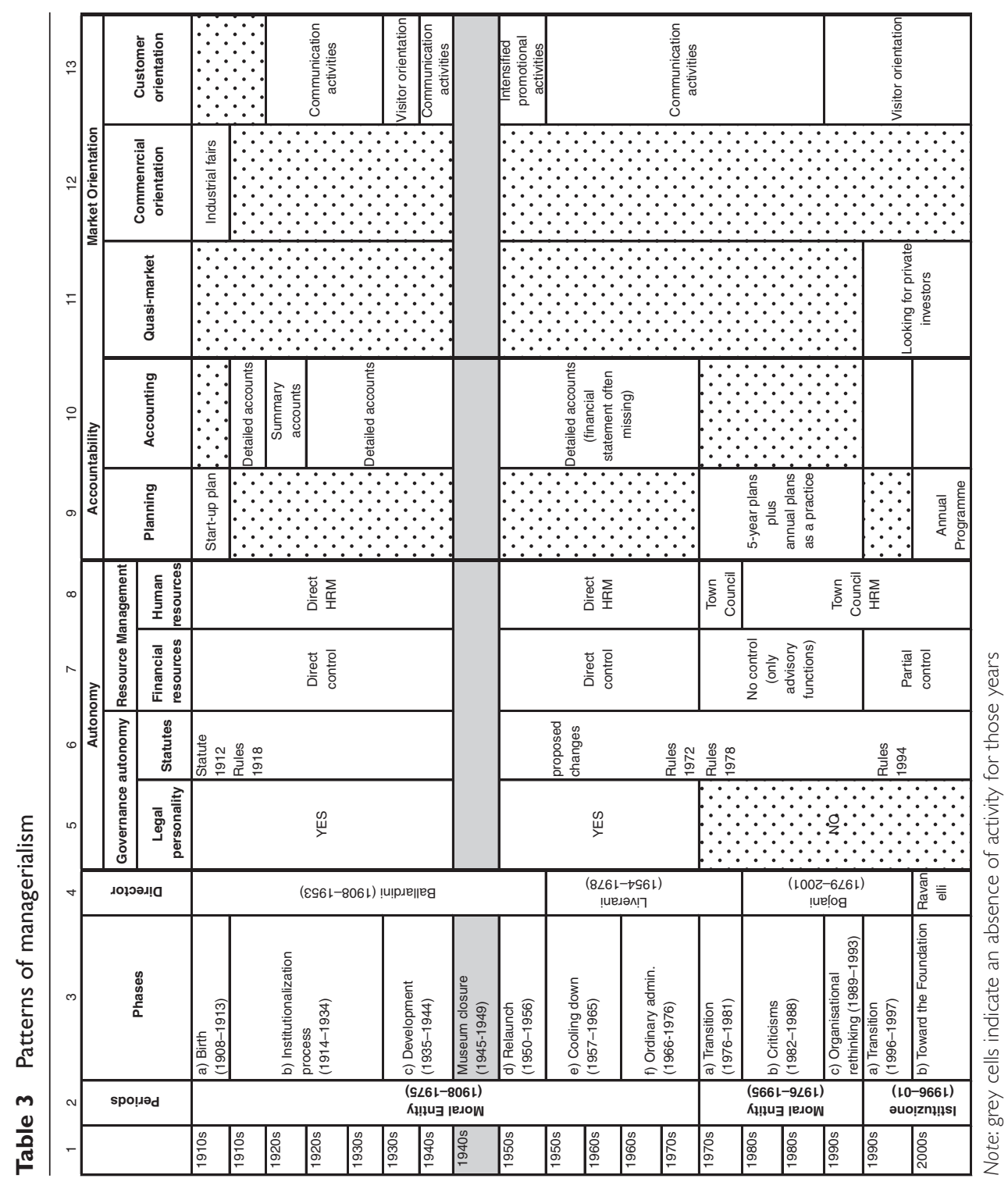


council. Moreover, as far as nomination policies were concerned, the members of the resident council were now totally appointed by the municipality and their mandate lasted 'as long as the town council which elected them', having just 'advisory functions to help with the management and running of the museum's activities' (regulation document 1972). In other words, the resident council became just a consultative branch of the municipal administration, losing all decisional and executive power. The consequences were at least twofold. First, there were difficulties in running the museum, due to the precarious situation of the board members. Second, there was total dependence upon the town council and the intrusion of political control. For example, upon approval of the new regulations document, one councillor stated:

I cannot approve as I do not believe that it is right that the Museum Council be completely appointed by the Town Council. In my opinion, the Town

Council Administration should only have appointed the 4 councillors and the other 4 should have been appointed by the Museum Council itself by meeting with the Body of Inspectors. The President of the Museum Council should be appointed by the Town Council Administration in accordance with the

Museum Council. Only in this way could the autonomy (if only in appearance) of its own management be saved. (RCM July 1977, italics added)

Governance autonomy was not recovered with the transformation into an Istituzione either, since the legal personality was not re-established (the Istituzione being just an instrumental branch within the municipality).

Statutes and identity-setting are crucial elements where governance autonomy is concerned. In the case of MIC, a statute and a regulations document were formulated at the very birth of the museum in 1908; since then the regulations were modified only twice (in 1978 and 1994, corresponding to the two governance transformations). The modifications concerned governance and organisational aspects (nomination of the board, juridical personality, personnel hiring policies, accountability and planning rules, etc.) linked to the changing institutional settings and to the changing level of discretion accorded to the resident council. Interestingly, despite all reforms, the substantive identity of MIC remained untouched: the goals included in the original statute were so topical that they remained unchanged over time and still constitute the profile of the museum today.

\section{Resource management}

Autonomy over resource management has been defined as the ability to control operational decisions, mainly concerning financial resources and human resources management. When MIC was a Moral entity, the resident council's discussions reflect the fact that the board had complete control over the administration of all collections and museum policies, as well as of financial and human resources (Table 3 , columns 7-8): the director and the councillors had the right to decide upon every 
issue without constraints. Instead, when MIC became a municipal museum the minutes record continuous complaints about the lack of vision on managerial issues regarding the museum (on costs, personnel, the town council's decisions, etc.). For example, in 1985 the resident council asked the municipal administration:

to redefine the Museum's role within the Town Council ..., to get to know the costs of the Museum personnel ..., to identify with certainty the costs of operations in mind, in order to avoid excessive demands. (RCM April 1985)

The role of the council itself is questioned:

The Director believes it is necessary that the Town Council Administration clarifies its intentions on the Museum. It in fact always complains about the difficulties it encounters.... As things stand - continues the director - one no longer knows who to turn to as the representative. If this has to only be the Town Council Administration, then the Council is a useless body, and in fact, the members of the Council can (with their requests or directives) more easily create obstacles than help. (RCM April 1986, italics added)

With the transformation into an Istituzione, much of the MIC's former managerial autonomy was re-acquired. Although its legal personality was not re-established, control over resources (MIC could manage its own budget again) and decisions were largely recovered. Indeed, the town council preserved the function of directing, programming and controlling the museum, but control over resources was formally granted to the Istituzione MIC. Museum initiatives and resource needs were negotiated every year between the resident council and the municipality; once the main lines and the resource amounts were agreed upon, the museum director had discretion on how to use the resources within those amounts. However, this all took time and did not result in an immediate definition of the resident council's various responsibilities and decision-making powers, as emphasised by one of the councillors:

Dr. B. [councillor] would like the Town Council Administration to tell the Museum Council what role it has and what power it actually has: He did not know that the Mayor's appointment did not automatically also mean a transfer of formal and significant managerial powers. (RCM September 1996, italics added)

A focus on human resources management (Table 3, column 8) deserves specific attention for its relevance in constituting an entity's managerial autonomy. Under the Moral entity, MIC had complete control of its human resources: personnel were at the dependence of the director and human resources expenditures (when explicitly expressed), were embedded in the museum's budget. However, mention is made sometimes of direct collaborations with the municipality and its staff (e.g. in 1952 the town council assigned a custodian to MIC, in order to relieve the museum of this expenditure) or with the ministerial personnel from the ceramic school (which since 1924 had passed on to the state administration). Data on staff 
numbers and positions are very rare in this period. In 1932 mention is made to 24 employees when both MIC and the school are considered (one director, 13 school professors, four technicians, three administrative employees, three custodians); in 1966 only 10 employees were registered (the director, a librarian, a curator, a photographer, two administrative employees, four custodians), and then 19 employees in 1972.

Under the municipal administration, human resources were completely managed by the town council. In the RCM frequent reference is made to requests of public competitions for hiring new personnel - requests that the councillors had to send to the municipality, since they were no longer empowered to recruit. During this period the only data available on human resources figures is a revision of the organisational chart in 1983; in this document the resident council asked the municipality to double the museum personnel (from 19 to 34 ).

Formally, with the Istituzione all museum staff members were civil servants from the municipality. No reference is found to the organisational chart or the staff numbers and composition.

One significant element needs to be stressed in terms of top management. Though connections with the business community changed over time, during the whole history of MIC the top management was provided by the public sector. Ballardini himself, the founder, was the Segretario Comunale (a sort of secretary general) of the municipality, and following directors also had a public sector background.

\section{Accountability}

Accountability has been defined as responsibility and transparency concerning the use of an entity's resources and the links between goals, means and results. Planning and accounting practices are its most typical manifestations.

\section{Planning}

As far as planning is concerned (Table 3, column 9), systematic forms of formal planning were missing for a long time and were instead introduced as a practice when MIC went public. From 1975, the practice of a five-year programme and, within it, of annual activity planning, was developed.

The planning method is based on the Institute's activities .... This also implies a commitment in defining the multi-year orientation of its activities in the field of ceramics and will mean making choices as regards the budget to define the method of controlling and checking the cultural situation. (Introduction to the five-year programme of 1975-1980, italics added)

Apparently, it is the guarantee of a stable, long-term regional funding, which came along with the transformation into a municipal museum, that allowed the development of long-range plans: 
The President explains the reasons for the devolution of the power to the Region and the benefit of having a protection law such as the LR 38/76 to organise the personnel and also to insure the legal means for the Museum's planning, which it had never had in the past. (RCM January 1977, italics added)

This practice was suspended with the transformation into an Istituzione. It was not clear who was responsible for the cultural programme at this stage of the transition, and for the first time after many years, in 1996 'there was neither an annual nor a multi-year programme with directions and aims' (RCM October 1996). The standstill could be due to the confusion of the transition phase. In fact in the following years as an Istituzione, MIC re-adopted the practice to formulate annual activity programmes as the basis for annual negotiations of objectives and resources with the municipality. However, longer-range planning practices were no longer present.

\section{Accounting systems}

To introduce the analysis of accounting representation procedures (Table 3, column 10), a preamble on the financial data is necessary. The first detailed accounts of the museum appeared in 1913. Prior to that, only start-up data (summary income and expenditures data referring to 1908-1913) were approved in bulk in 1913 and entered retrospectively into the administrative system. As a Moral entity, in the first decades of activity (1913-1944) MIC was mainly breaking even; just 1915 showed a deficit, due to the collapse of public subsidies, which was soon recovered the following year. On expenditures, the number of items soon increased, signalling a broadening of museum activity; in particular, the journal and the ceramic school were the most important items in terms of expenditure amounts. After 1924, the school was no longer budgeted by the museum, but an annual transfer from the museum to the school continued until 1941. A specific item for 'personnel' only appeared for few years (1924-1928) in the museum accounts during this period. On income, most resources came from public grants; earned income was modest and - when present derived from museum entrance fees (except for 1924-1928, until the 1950s MIC had free admission), and from journal sales. In terms of amounts, between 1920 and 1943 income stabilised at around 20,000 lira. All in all, the stability of running expenditures and of economic results corroborates the idea of a stable period in the museum's operations in this first phase of the Moral entity.

After the Second World War, the reconstruction of the museum was associated with a constant increase: from 1 million lira in 1951 to 23 million liras in the 1970 s. (For a long-term comparison, of course these should be deflated, but what matters here is the year-to-year evolution, so we can still work with nominal values.) Personnel expenditures appeared only from 1968 with values around 4-6 million lira. There is no mention in the minutes of particular financial tensions in this period.

MIC accounts for its municipal period (1976-1996) must be enucleated and reconstructed from the itemised budgets of the municipality. What emerges is a 
situation of deficit, with expenditures and income increasing substantially as never before. An effort to reduce expenditure between 1991 and 1994 can be noticed; however, amounts increase further in 1995 and double in 1996. Nothing can be said about personnel expenditures in this period, since they were mixed with the overall expenditures for the municipal personnel.

As an Istituzione, the situation is quite stable: in terms of amounts, MIC reports income and expenditures of about 3 billion lira, reaching even some little surplus (around 100,000 lira) between 1997 and 1999. A deficit is registered in 2000, due to an increase in all expenditures, paralleled by a slight decrease in both public funding and earned income. Only in 1997 is there a separate item for 'personnel'; in the following years it seems that personnel expenditures are collapsed into the item 'services', comprising $90 \%$ of the overall expenditure.

As shown in Table 3 (column 10), under director Ballardini, MIC was completely accountable for resources, although in non-sophisticated forms. The first estimated budget was done in 1913. Since then the minutes show evidence of annual discussions of the budget and of external auditing on the financial statement.

At a later stage (1950s-1970s, i.e. under director Liverani, when MIC was still a Moral entity), budgeting and reporting practices seem to be carried out at a minor level and on a ritualistic basis. Indeed, the budget was always presented, discussed and approved with notable delay; often variations were made to the budget estimates which had already been approved; or for example the financial statements from 1961 to 1963 were approved 'in bulk' in 1964. In sum, resources made up a theme of everdeclining importance in the councillors' discussions.

An important discontinuity took place with the transformation into a municipal entity: the accounting system of the museum was substituted with the broader procedures of the municipal administration. MIC had just a partial budget, with reference to its programme of activities, agreed upon with the town council, and included in the town council budgets under the item 'MIC' (RCM February 1981). The basic characteristics of accounting representation in the Italian public sector here emerge: the museum, as such, lost its accounting identity and the global assessment of income and expenditures; moreover, important items in the functioning of the museum were aggregated according to the general items of the municipal accounting representation (e.g. personnel expenditures were presented as a whole in the municipal reports, without allocating costs to specific entities or cost centres).

With the next transformation into an Istituzione, the museum was provided with its own accounting system again. MIC developed a more accurate and complete accountability, with comprehensive budget to be reported to the town council. At this stage, a 'normal' structure for the financial statement according to EU directives was introduced. However, this did not actually happen until 1997. In fact, in the first fiscal year the councillors lamented that 'there was no real budget to refer to' (RCM September 1996) and requested the creation, within the museum, of a suitable administrative unit. In sum, with the Istituzione a discourse on resources had become central again. It is interesting to notice, at a procedural level, that after 1997 
budgets and financial statements were again discussed on time: aa stark contrast to the anarchy and late approvals 10 years earlier.

\section{Market orientation}

Market orientation is conceived in the NPM literature as quasi-market, commercial orientation and customer orientation.

\section{Quasi-markets}

The openness of MIC to the market in terms of private investors or contracting-out solutions is something that had been a stranger to the administrative history of MIC for many decades (Table 3, column 11). A discourse of quasi-market had been emerging with insistence since 1998, in the late stage of the Istituzione. Indeed, the Istituzione had 'been thought of, even at the beginning, as an intermediary move', as a 'transitory and precarious period' (RCM March 1998) between the direct municipal administration and more radical form of autonomy: the private foundation. All RCM minutes in 1999-2000 record continuous interactions and negotiations between the president of MIC and a number of potential public and private partners for the foundation project (namely, the provincial administration, the local chamber of commerce, two private bank foundations and others).

\section{Commercial orientation}

The initial concept of the museum was strongly characterised by a commercial orientation (Table 3, column 12). This is already evident in the very first meeting of the resident council, when the members discussed the nature of the future museum exhibitions: they spoke about 'art and industrial ceramics' (RCM 1908) and about the possibility of combining the exhibition aspect and the trade fair aspect for the museum 'which would take on its real practical, commercial meaning' (RCM 1908), on the model of the Lipsia fair. Therefore, it was originally intended for the museum to become a research centre specifically designed for trade fairs and events, to 'reintroduce the ancient ceramic art' (RCM 1908). Indeed, the commercial nature of the original museum concept was lost throughout time in favour of a less-innovative concept. Less and less evidence of participation to industrial fairs is found in the minutes and no mention of hosting ceramic trade fairs is ever made.

\section{Customer orientation}

Since the 1920s, issues regarding communication, marketing activities and additional services at the museum (e.g. a museum shop for ceramics souvenirs), although not central, were always at stake in the discussions on a regular basis (Table 3, column 13). In the 1950s, with the relaunch of the museum after the destruction by bombing, increasing attention was paid to marketing. The need to promote the museum was in fact a central issue, and an item specifically designated for 'advertising' was introduced in the budget from 1951. Communication activities included: postcards and 
publications for sale at the entrance of the museum; signs, flyers or other pamphlets; the introduction of entrance ticket postcards; and the inclusion of the museum in tour operator programmes. Still on the customer orientation side, there is evidence that very early at MIC it was no longer only the heritage aspect which was of interest, but also the quality of the visitors' experience. For example:

$\ldots$ in order to facilitate the visit to the museum's premises, the Council ponders over whether to include a map at the entrance of the premises themselves. (RCM May 1934)

or better still:

... considering the fact that with the current development of the museum, the visitors might well need to rest a little ..., the Council considers the possibility of giving the museum a congruous number of suitable chairs to furnish the rooms, to be used by the visitors. (RCM June 1934)

Although routine communication activities continued through time, such an explicit reference to visitors' experience disappeared until the 1990s. In the 1990s, the museum stopped acquiring objects to increase its heritage and instead expanded the organisation of events. This marked a shift in the museum's priorities (from the 'object' to the 'public'): compared to the past, priority was now given to activities concerning the public rather than to increasing the museum's collections.

\section{Discussion}

We reconstructed the MIC administrative history on the base of archival sources. This allowed us to trace and disentangle several patterns of managerialism over a century and hence bridge two conflicting interpretations: the one carried out by museologists, and the one that would emerge from the application of mainstream NPM literature to this case.

Where the issue of autonomy is concerned, we found that MIC as a Moral entity had some strong autonomy both in its governance and in resources management, and that both were lost when MIC went public (except for a reacquisition of a partial control over resources under the Istituzione in the late 1990s). Autonomy then is not an 'invention' of the last decades' NPM reforms: in the case of MIC, it was there for almost 70 years, then 'stolen' during the process of étatisation. One of the most fascinating (and surprising) elements in reading the archives is indeed the dynamics related to the choice of becoming public. Seeing things from our time, in a context of widespread cuts in public sector budgets, the rationale for this might seem ironic: to get money (more funds and in stable ways). Moreover, it is curious how the resident council members slowly realised that the new public status was providing resources at the expense of their autonomy and control. 
Another core element of public management reforms related to autonomy is the emphasis put on the elaboration of 'mission statements', goals and the like. The 'trendy notion' of mission, to use Smith's (1996) sarcasm once again loses its appeal in this approach. In the case of MIC, in fact, the adoption of a statute with a clear statement of goals is not a recent innovation of managerialism at all: instead, it has accompanied the elaboration of the museum concept since its very birth and, interestingly, it did not change substantially over time.

These findings, then, tend to support the museologists' view on the managerial modernity of MIC since its foundation, and to some extent disprove the NPM view of managerialism as the outcome of recent reforming processes.

As far as accountability is concerned, we found that planning was a practice that characterised MIC at the start-up phase and then all along the municipal administration. Accounting practices were central as long as the museum was a Moral entity, then completely disappeared under the public administration but were later reinstated under the Istituzione. Taken together, these results show that planning and accounting activities have always been decoupled and hence that a complete accountability system has always been virtually missing. This allows us to deemphasise both the museologists' view and the NPM view. However, what remains certain is that no accounting practices such as budgeting and reporting or formal planning are an innovation introduced with the NPM reforms.

As for market orientation, what emerges is that a commercial inclination strongly characterised the museum concept at the foundation stage and that a focus on marketing and customer care has more or less always been present at MIC: these results tend to support the museologists' view. However, consistently with the NPM view, notions of quasi-market (in terms of privatisation) have been in the discussions of the resident council since the late 1990s and were clearly brought in by the broader NPM trends. The subsequent transformation of the museum into a private operational foundation is the most evident sign of such a trend.

In addition, our analysis addresses the issue of the rhetorical nature (in part) of the notion of modernity maintained by the museologists' view. Indeed, a distinction should be made between the museum concept in the mind of the founder and what was afterward realised and when. The museology narrative seems to confuse the modernity of Ballardini's concept with the modernity of the institution, assuming that what is put in words and plans is translated into action by itself. Actually, much of the intentional strategy was realised. Some things were achieved only in part (e.g. the school project: the ceramic school was soon externalised to the state administration, becoming a separate entity in 1924), others were established only later and incrementally (e.g. the international ceramic competition: a local competition for ceramic artists was established in 1938 but only became international in the 1950s).

Moreover, a process view of the museum and of decision-making would highlight the importance of the multiple roles played by a variety of actors (see the notion of 'constellation of roles', Normann 1977). Without willing to de-emphasise the 
unquestionable strength of Ballardini's leadership, it should be acknowledged how MIC (especially in its origins) has been a collective project in which the contribution of many actors (e.g. the role of the donors, the role of politicians, etc.) has been essential in shaping the museum's strategy. Also, public funding supported almost all monetary and human resources needs in the whole period.

\section{Concluding remarks}

What was there before NPM? And what about modernisation at MIC? Is this a story of a modern and proactive entity since its origins, or is modernity the outcome of the recent transformation from public sector bureaucracy towards managerialism? These were the issues this paper tried to address with reference to MIC's history.

The impossibility of achieving a straightforward answer to our empirical question is an interesting finding in itself. One of the most fascinating elements in this history is the long-term 'swing' that the case history describes: from private, to a phase of 'statisation' (étatisation), then back to private status again. An analysis of archival documents, taking the complexity of change over time seriously into account, makes it impossible to achieve any linear, clear-cut view of the transformation with reference to the individual case.

Certainly MIC is a unique organisation with a unique history in a unique context. In no way do we wish to generalise from that. We do not state that the complex pattern of swing back and forth in managerialism at MIC is the way public management has developed more generally. We argue that each context - and even each entity - has its own idiosyncratic history. Nevertheless, this specific case history has something to teach at a broad level too: the fact that when opening the black box of an entity's history and digging into it, one may find complex (often unexpected) situations that may question more trivialised - largely non-archival based, and to some extent ahistorical in nature - reconstructions of evolution of managerial 'needs' and 'conditions', which often characterise the management debate in general (e.g. Johnson and Kaplan 1987) and public management debates in particular. Moreover, disentangling and reflecting separately on different aspects of managerialism may better capture the complexity of change and overcome the shortcomings of many simplistic debates.

All in all, what the case seems to suggest is the relevance of specific elements in understanding individual (long-term) processes of change. We are not so much concerned with the degree of representativeness of the MIC case, something that will deserve a research of its own (though the century-long, resilient history of not a few arts organisations should not be forgotten, such as the British Museum, La Scala, or Pompeii: see Boylan 1992; Smith 1996; Zan 2006). Adopting a historical view provides a deeper, more complex and contextual understanding of changes, both at the level of individual organisations (such as MIC) or at the level of general 
phenomena (such as 'managerialisation' processes of museums or, more generally, of the public sector), to a large extent missing in NPM literature. In other words, historical analysis is necessary in advance of the current debates, which are too much and too often focused on short-term views based on macro processes, within non-specific and overly abstract analyses, which lead to partial, and above all superficial, understandings of change. Indeed, if we want to explain the process of the public sector becoming what it was not - to paraphrase Hopwood (1987) - we must understand what it was before: if not, even our understanding of its current meanings will be weakened.

If the consequences of a lack of serious historical investigations are clear enough, identifying the reasons of such a lack is more complex, and changing this situation much more difficult. Perhaps it is time to start a discussion on the rewarding system in the management field and its perverse effects on validating research.

\section{Acknowledgements}

Several people have been instrumental in allowing this paper to be completed. We would like to thank especially the current director of MIC, Jadranka Bentini, the president and all the museum management representatives, for their support and collaboration in our extensive exploration of the museum archival documents.

\section{References}

Balzani, R. 2008. 'Fra Arte Antica i Industrie Nuove. Gaetano Ballardini e la Tutela del Patrimonio Culturale.' In Faïence: Cento Anni del Museo Internazionale delle Ceramiche in Faenza, edited by J. Bentini. Torino: Allemandi \& C.

Bentini, J. 2008. 'Passione e Perseveranza. Nutrimenti per la Crescita di un Museo.' In Fä̈ence: Cento Anni del Museo Internazionale delle Ceramiche in Faenza, edited by J. Bentini. Torino: Allemandi \& C.Bowerman, M. 1996. 'The Rise and Fall of Value for Money Auditing.' In Accounting and Performance Measurements. Issues in the Private and Public Sectors, edited by I. Lapsley and F. Mitchell, 193-212. London: Paul Chapman Publishing.

Boylan, P. 1992. 'Revolutionary France and the Foundation of Modern Museum Management. Museum Management and Curatorship 11: 141-52.

Brunsson, N., and K. Sahlin-Andersson. 2000. 'Constructing Organizations: The Example of Public Sector Reform.' Organization Studies 21(4): 721-46.

But, H., and B. Palmer. 2000. Value for Money in the Public Sector. Oxford: Basil Blackwell.

Ferlie, E. 2002. 'Quasi Strategy: Strategic Management in the Contemporary Public Sector.' In The Handbook of Strategy and Management, edited by A. M. Pettigrew, H. Thomas, and R. Whittington, 279-98. London: Sage.

Gruening, G. 2001. 'Origin and Theoretical Basis of NPM.' International Public Management Journal 4(1): $1-25$.

Hemel, A., and N. van der Wielen. 1997. Privatization/de'se'tatization and Culture. Limitations or Opportunities for Cultural Development in Europe? Amsterdam: Boekman Foundation, Jubels/ Copypoint. 
Hood, C. 1991. 'A Public Management for all Seasons?’ Public Administration 69: 3-19.

Hood, C. 1995. 'The New Public Management in the 80s: Variations on a Theme.' Accounting Organizations and Society 20: 93-110.

Hopwood, A. G. 1987. 'The Archeology of Accounting Systems.' Accounting, Organizations and Society 12(3): 207-34.

Johnsen, A., and I. Lapsley. 2005. 'Reinventing Public Sector Accounting.' Financial Accountability and Management 24(1): 77-95.

Johnson, H., and R. Kaplan. 1987. Relevance Lost: The Rise and Fall of Management Accounting. Boston: Harvard Business School Press.

Lapsley, I. 1988. 'Research in Public Sector Accounting: An Appraisal.' Accounting, Auditing and Accountability Journal 1(1): 21-33.

Lapsley, I. 2008. 'The NPM Agenda: Back to the Future.' Financial Accountability and Management 24(1): 77-95.

Lindkvist, L., and S. Llewellyn. 2003. 'Accountability, Responsibility and Organization.' The Scandinavian Journal of Management 19(2): 251-73.

Lusiani, M., and L. Zan. 2009. '100 Years of Administrative History of the International Museum of Ceramics.' Social Science Research Network. http://papers.ssrn.com/sol3/papers.cfm?abstract id $=1656634$.

Normann, R. 1977. Management for Growth. Chichester: John Wiley and Sons.

Pollitt, C. 2002. 'Clarifying Convergence: Striking Similarities and Durable Differences in Public Management Reform.' Public Management Review 4(1): 1-22.

Smith, A. W. 1996. 'Is the British Museum Losing its Marbles?' The Independent, November 18.

Zan, L. 2004. 'Accounting and Management Discourse in Protoindustrial Settings: The Venice Arsenal in the Turn of the XVI Century.' Accounting and Business Research 32(2): 145-75.

Zan, L. 2006. Managerial Rhetoric and Arts Organizations. New York, NY: Palgrave MacMillan.

Maria Lusiani is a Ph.D. candidate of the Department of Management, University of Bologna, Italy. Her main research interests cover public sector studies and managerialism, discourse perspectives in organization studies, strategic management and professional-management tensions. Her research focuses on public, professional services in the fields of culture and healthcare. maria.lusiani@unibo.it

Luca Zan is Professor of Management and Director of the Graduate degree in Innovation and Organization of Cultural and the Arts (GIOCA) at the University of Bologna, Italy. Research interests cover the areas of strategic management and change, management and accounting history. A major focus is on Cultural Organizations and Museum Management. luca.zan@unibo.it 